\title{
RUANG SAKRAL DAN RUANG RITUAL PROSESI ADAT PERNIKAHAN SINTÊ MUNGÊRJÊ PADA MASYARAKAT GAYO LÔT
}

\author{
Indra Setia Bakti ${ }^{1)}$, Khairul Amin, Fakhrurrazi \\ ${ }^{1}$ Program Studi Sosiologi FISIP Universitas Malikussaleh, indrasetiabakti@ unimal.ac.id
}

\begin{abstract}
Rational and empirical human dominate modern society. But in practice, modernity often lacks reflection. Wedding processions in modern Gayo communities illustrate this reality. The depth of meaning through symbols and social actions in every stage of the traditional Gayo wedding procession is beginning to be displaced by the ceremonial lack of understanding that tends to be rushed and infiltrated by global culture. This study documents the knowledge and subjective meaning of Gayo traditional actors regarding the tradition of sintê mungêrjê marriage by identifying sacred spaces and ritual spaces, then how the modern Gayo people interpret and act based on the observations of research informants. This qualitative research uses in-depth interview techniques in the data collection process. This research found that the essence of sintê mungêrjê was spirituality and communality nuances characterized by sacred and ritual activity stages. However, this set of norms is no longer institutionalized during modern Gayo society. This condition makes ritual meaningless and presents a culture without a clear personality identity.
\end{abstract}

Keyword: Sacred, Ritual, Wedding Procession, Sintê Mungêrjê, Gayo

\begin{abstract}
ABSTRAK
Masyarakat modern didominasi oleh manusia yang bercirikan rasional dan empiris. Tapi dalam praktiknya, sering ditemukan fenomena modernitas minim refleksi. Hal itu sebagaimana pelaksanaan prosesi adat pernikahan pada masyarakat Gayo modern. Kedalaman makna yang ditampilkan melalui simbol dan tindakan sosial dalam setiap tahapan prosesi adat pernikahan Gayo tradisional mulai tergeser oleh seremonial minim pemahaman yang cenderung tergesa-gesa dan disusupi budaya global. Studi ini mendokumentasikan pengetahuan dan makna subjektif para pelaku adat Gayo mengenai tradisi pernikahan sintê mungêrjê dengan mengidentifikasi ruang sakral dan ruang ritual, kemudian bagaimana masyarakat Gayo modern memaknai dan bertindak berdasarkan pengamatan informan penelitian. Penelitian kualitatif ini menggunakan teknik wawancara mendalam dalam proses pengumpulan data. Berdasarkan hasil penelitian diperoleh pemahaman bahwa hakikat sintê mungêrjê adalah spiritualitas dan komunalitas yang diwarnai oleh tahapan kegiatan yang bersifat sakral dan ritual. Namun seperangkat norma ini tidak lagi terinstitusionalisasi di tengah masyarakat Gayo modern sehingga hanya melahirkan ritual miskin makna dan budaya tanpa identitas kepribadian yang jelas.
\end{abstract}

Kata Kunci: Sakral, Ritual, Prosesi Pernikahan, Sintê Mungêrjê, Gayo 


\section{PENDAHULUAN}

Eksistensi adat budaya Gayo dalam prosesi pernikahan senantiasa dihantui ancaman dari luar. Fenomena globalisasi informasi, materialisme, konsumerisme, dan kawin silang menantang upaya pelestarian orisinalitas nilai-nilai kearifan lokal, khususnya dalam tradisi pernikahan. Keterputusan informasi dari satu generasi sebelumnya turut melahirkan reifikasi (Bakti, et al., 2020) dan memposisikan adat budaya Gayo berpotensi terlupakan bahkan ditinggalkan oleh generasi baru.

Perubahan sosial sudah banyak terjadi di tengah masyarakat. Nilai-nilai kebudayaan Gayo, menurut salah seorang tokoh adat yang menjadi informan penelitian, masih terjaga kemurniannya hingga era 1970-an. Ketika memasuki era 1980-an, nilai-nilai baru yang berasal dari luar Gayo mulai diintrodusir. Sementara grafik perubahan sosial sangat terasa peningkatannya di tengah masyarakat pasca tsunami yang melanda Aceh sekitar akhir tahun 2004.

Perubahan itu merembes pula ke dalam prosesi adat istiadat pernikahan di Tanah Gayo. Beberapa tahapan penting dalam prosesi pernikahan menghilang atau sudah ditinggalkan. Minimnya pemahaman atas makna yang terkandung dalam setiap tahapan prosesi pernikahan menambah buruk keadaan. Mis-informasi ini terkadang melahirkan stereotip dan prejudice terhadap adat Gayo yang dinilai terlalu merepotkan (ribet) dan bertele-tele oleh generasi Gayo sendiri. Lebih parah lagi, masyarakat modern ditandai oleh sebuah kesadaran yang ingin serba cepat dan instan (Siregar, 2019) karena struktur yang ada sekarang mengekang dan memaksa individu menjadi demikian adanya.

Kondisi ini terus berlanjut, memunculkan kekhawatiran dari para pelaku adat. Masa depan kebudayaan lokal menjadi semakin suram. Godaan yang menerpa dari luar memaksa banyak anggota masyarakat menganut nilai-nilai global yang bercorak satu dimensi (Marcuse, 1991) sehingga semakin melupakan kepribadian aslinya sebagai suatu bangsa yang unik yang pernah ada di muka bumi.

Berdasarkan pemaparan singkat di atas, kajian ini kiranya bertujuan untuk menggambarkan prosesi adat pernikahan sintê mungêrjê pada masyarakat Gayo Lôt. Studi ini cukup mendesak dilakukan sebagai bentuk pendokumentasian kearifan lokal yang dikhawatirkan punah seiring dengan kepergian para pewaris pengetahuan yang rata-rata sudah berusia senja. Melalui studi ini, peneliti mencoba melihat relasi sosial yang terjadi dalam setiap tahapan prosesi pernikahan dan melakukan identifikasi ruang sakral dan ruang ritual yang turut membingkainya berdasarkan pemahaman yang diperoleh dari para informan penelitian. 


\section{METODE PENELITIAN}

Penelitian ini mendokumentasikan cadangan pengetahuan (stock of knowledge) dan pandangan-pandangan tentang prosesi pernikahan sintê mungêrjê dari para pemikir, pemerhati, dan pelaku adat Gayo di Kabupaten Aceh Tengah. Penggalian data dilakukan dengan metode wawancara mendalam (indepth interview). Pilihan ini sangat dimungkinkan karena tema yang dikaji tidak berpotensi menghasilkan resistensi dari para informan penelitian. Data berupa keterangan dari para informan dibandingkan, diselaraskan, dan dikonstruksi seperti menyusun kepingan-kepingan pengetahuan yang dikuasai oleh masing-masing informan yang disesuaikan dengan tujuan studi ini. Dalam studi di lapangan peneliti menjadi bagian dari kelompok yang diteliti atau sebagai anggota komunitas masyarakat Gayo. Posisi ini menghadirkan realitas dalam dua suara, yaitu suara akademis dan suara reflektif yang lebih pribadi (Marvasti, 2004).

\section{HASIL DAN PEMBAHASAN}

\section{Prosesi Adat Pernikahan Sintê Mungêrjê}

Dalam pemahaman adat Gayo, setiap orang tua memiliki utang hidup yang wajib ditunaikan bila sampai pada waktunya. Konsep tentang utang hidup ini dikenal dengan sebutan sintê môrep (Bowen, 1984; Aman Pinan, 2001; Ibrahim \& Aman Pinan, 2009). Salah satu utang orang tua dan mungkin sebagai utang hidup yang terakhir ialah menyelenggarakan prosesi pernikahan anaknya yang disebut sintê mungêrjê. Prosesi sintê mungêrjê melalui tahapan yang sangat panjang, dimulai dengan proses mencari jodoh.

Ketika usia seseorang sudah dewasa (dalam bahasa Gayo disebut sudah bujang), kebiasaan di Tanah Gayo mengarah pada terjadinya dialog yang dilakukan antara anak dengan orang tuanya. Dialog berfungsi sebagai ruang komunikasi yang bersifat pribadi dengan maksud mencari calon istri yang cocok dijadikan sebagai pasangan hidup. Hal itu diungkapkan dalam pepatah Gayo dengan tamsil: "mërahi bêlang si gêrê ilên mupancang, mërahi utên si gêrê ilên bêtênê" (bermakna: "mencari lapangan yang belum dipancang, mencari hutan yang belum bertanda"). Memilih "teman hidup" bisa terjadi dalam tiga kemungkinan skenario, yaitu pilihan anak sendiri, ditawarkan oleh orang tua, atau saling dipertemukan (ta'aruf). Salah seorang tokoh adat Gayo menuturkan proses mencari calon istri sangat memungkinkan untuk melibatkan banyak pihak dari kalangan keluarga dekat sebagaimana petikan wawancara berikut:

“... Jadi mungkin anak yang menunjukkan 'sô nong' ('saya dengan yang itu'). Itu kalau bahasa Gayonya disebut: 'sênê gubak sênê gurê, sênê kêkanak ngê sawah ku jêma tuế'. Itu berarti ada kenalannya. Maka itu direnung saran... Kemudian kalau dia belum punya... 'Kalau begitu nak, bagaimana kalau si Polin itu?' Itu berarti 'bêrakah i dëlah sênê i têlêgê,, 
sênê bêrakah ngê sawah ku têtuê', bermakna kita yang tunjukkan kepadanya... Atau keduaduanya tidak ada, sama-sama dicari... dipertemukan... Supaya jangan sumang... dituntun oleh orang tua, kadang (dua keluarga itu) pergi minum ke warung sana, mereka berbicara dari hati ke hati..." (Yusin Saleh, Kampung Bujang, 02/11/2019)

Skenario apa pun yang dilalui dalam tahapan ini akan mengarah kepada penentuan satu sosok. Bila pilihan sudah dilabuhkan, tahapan yang tidak boleh dilewatkan yaitu meneliti calon dimaksud. Proses penilaian calon istri melibatkan keluarga luas (extended family) dalam sebuah forum tukar pendapat yang dikenal dengan sebutan "bêrise kono kilo kintë". Keluarga luas ini bisa terdiri dari ayah, ibu, kakek, nenek, saudara kandung, serta saudara kandung ayah dan ibu. Sementara penilaian terhadap calon yang dituju berpedoman pada ajaran agama Islam (Islami, 2018), seperti penjelasan informan:

“... walaupun ditunjukkannya kepada kita, sudah pastikah itu diterima? Barulah orang tua dengan keluarga dekat... entah itu pak cik (paman), pak kul (wawak), bibik (tante) berkumpul, 'itulah calon yang ditunjuk anak kita', maka mereka "bêrise kono kilo kintë". Artinya mempertimbangkan, meneliti, menelaah bagaimana agamanya, bagaimana akhlaknya, bagaimana hartanya, bagaimana keturunannya...." (Yusin Saleh, Kampung Bujang, 02/11/2019)

Keterlibatan keluarga luas berfungsi menyelidiki calon yang akan dipilih, dikenal dengan sebutan: amal tidur nipi jêgê. Namun keterlibatan ini tidak boleh disalah-artikan dengan sewenangwenang. Forum keluarga hanya berkewajiban memberikan pertimbangan dan saran, dalam arti kata bukan memaksa atau mewajibkan pilihan kepada anak. Dalam kegiatan ini, sangat ditekankan kedewasaan berpikir dari bujang yang menjadi calon pengantin tersebut. Ia harus menentukan sendiri jalan hidupnya dan berani membuat keputusan yang terbaik bagi diri dan keluarganya. Realitasnya dialog yang terjadi dilakukan secara terbuka dan blak-blakan. Apabila di dalam hasil penyelidikan terdapat hal negatif terhadap calon yang dituju biasanya disampaikan di dalam forum tersebut. Petikan wawancara dengan informan berikut memberi gambaran lebih lanjut:

“... apabila di situ ada negatif... disampaikan kepadanya. 'Ini negatifnya bila engkau bersamanya, bagaimana kata hatimu?' Tetapi tidak harus memotong tidak jadi, tidak! Artinya kalau sudah habis disampaikan, itu juga pilihannya (pilihan si bujang)... Cocok, kalau begitu kami (keluarga) mengikuti... itulah yang meresap ke calon pengantin... maka di sini tidak ada penyesalan di belakang hari apabila pun ada kejadian karena sudah sejak awal dikaji..." (Yusin Saleh, Kampung Bujang, 02/11/2019)

Bilamana pemuda tersebut, setelah mempertimbangkan saran dari forum keluarga, ternyata hasilnya positif atau telah menambatkan hatinya pada calon yang dituju, maka tahap selanjutnya adalah melakukan penjajakan dengan keluarga yang bersangkutan. Dalam adat Gayo, inisiasi dilakukan dengan cara mengirimkan seorang kurir atau utusan. Ia bertugas menyampaikan pesan 
ketertarikan meminang gadis (bêru) dimaksud kepada wali gadis itu. Utusan dipilih dengan kriteria

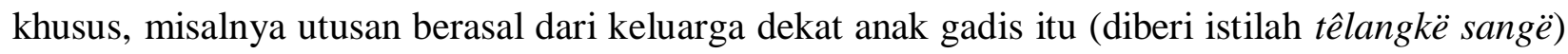
atau utusan adalah seorang kerabat, teman, atau tetangga yang sama-sama dikenal, baik oleh pihak keluarga bujang maupun pihak keluarga bêru yang dituju (diberi istilah kêkêlang rukut). Mengirimkan utusan sebagai langkah penjajakan memuat makna tersendiri. Hal ini dilakukan dalam rangka menghindari resiko malu pada pihak keluarga bujang andaikata niat baik mereka ternyata ditolak oleh pihak keluarga bêru yang dituju.

“... Dikirim kurir dulu, orang Gayo ini tidak boleh langsung. Kalau bahasa kita namanya têlangkë sangë... siapa saudara wanita yang mau kita tuju itu... bukan ayah atau ibunya... ke tantenya umpama. 'Hai Mak Polan, kami ada rencana mau datang ke rumah anak gadis yang di Bebesen sana, bagaimana itu? Boleh kami datang?' Lalu katanya, 'O baiklah kalau begitu, sudah ku dengar ini... berunding dulu kami, ku bawa kabar ke abang tu'... Ayahnya anak itu...." (Aspala Bantacut, Kampung Mendale, 09/11/2019)

“... pertama sekali mengetok pintu itu... kalau bahasa Gayonya kêkêlang rukut... bukan dari pihak keluarga laki-laki... itu kalau dia tolak nanti jadi malu. Jadi diutus siapa yang kita percaya... dia (utusan itu) ramah dengan mereka, kebetulan ramah juga dengan kita..." (Yusin Saleh, Kampung Bujang, 02/11/2019)

Kedatangan utusan menyampaikan maksud baik dari sebuah keluarga akan direspon tuan rumah dengan cara yang baik pula. Umpan balik bisa saja langsung diberikan apabila ayah dari anak gadis itu sudah mengetahui dan sangat tidak menyukai tabiat dari pemuda yang punya ketertarikan tadi. Maka hampir bisa dipastikan kalau jawabannya diberikan secara langsung bermakna menolak. Namun situasi yang umumnya terjadi adalah jawaban dari keluarga anak gadis itu dipending/ditunda atau baru diberikan dalam jangka waktu beberapa hari ke depan. Sang ayah akan berkata bahwa mereka juga hendak bermusyawarah dengan anak gadisnya yang juga melibatkan keluarga dekatnya terlebih dahulu.

Dalam proses penjajakan ini, sejumlah simbol ditampilkan. Simbol atau tanda memiliki makna tersendiri bagi orang Gayo. Dalam mengemukakan sebuah kehendak, semakin tidak langsung prosesnya semakin sopan nilainya. Maka pihak keluarga pemuda yang memiliki maksud biasanya mengirimkan atau menitipkan tanda kepada pihak keluarga pemudi yang dituju. Hal ini disebut dengan istilah mujulê pêramalan yang menunjukkan betapa halusnya adat budaya Gayo. Tanda yang dititipkan umumnya berupa amplop berisi uang (dimana jumlahnya tidak ditetapkan) yang disisipkan di sela-sela beras dalam sebuah wadah yang disebut tapë. Pemaparan berikut ini menambah pemahaman tentang tanda dimaksud:

“... Kalau ada seorang pria yang suka sama wanita di kampung kita ini, dia mujulê pêramalan ini sebelum dia melamar... Di situ dia memberikan sejenis... amplop yang 
isinya mungkin uang. Itu tanda kan... uangnya terserah lah berapa isinya. Kita ga tentukan berapa isinya tu. Itu dikasih sama calon besan oleh orang tua si calon mempelai laki-laki tu... di situ dititipkan lah amplop itu sebagai tanda, itu awal cerita terjadinya sintê mungêrjê itu kan... Setelah itu, ditunggulah tiga hari paling cepat...." (Tgk. Ikmal, Kampung Lot Kala, 09/11/2019)

“... peralatannya itu kan sebagai simbol. Penyerahan simbol itu apa? Ini tênê (tanda) kami sungguh-sungguh meminang anak anda itu...." (Yusin Saleh, Kampung Bujang, $02 / 11 / 2019)$

Ketika tanda sudah disampaikan kepada pihak keluarga anak gadis yang dituju, orang tuanya lalu mengumpulkan keluarga dekat guna menjalankan "bêrise kono kilo kintë" di pihak mereka. Prosesnya kurang lebih sama dengan yang dilakukan oleh pihak keluarga si pemuda tadi. Dalam proses ini, keputusan menerima atau menolak untuk dilamar tetap diserahkan pada anak gadis (bêru) itu. Adapun keluarga dekatnya hanya memberikan pertimbangan-pertimbangan atau saran-saran dengan tujuan pendewasaan berpikir.

“... Mulai dari awal kita harus ketahui dulu... latar belakang yang mau meminang itu... ini dari keturunan yang seperti apa, kehidupan sehari-harinya seperti apa, dia itu berorang tua itu seperti apa... tentang ilmu pengetahuannya itu seperti apa. Jadi kalau kita lihat dari cerita-cerita orang zaman dulu, orang kita ini tidak terlalu mengedepankan titel gelar, tetapi lebih kepada akhlaknya... Itu yang sakral betul itu, yang harus diketahui dulu..." (Dr. Joni MN, M.Pd, Kampung Pinangan, 09/11/2019)

"... Itupun mungkin kalau gitu "berpikir dulu kami selama tiga hari ini.... itu dia ikut "bêrise kono kilo kintë". Mereka yang penting-penting dikumpulkannya. 'Nah itulah yang datang, bagaimana perasaanmu?' kan dia teliti kita lagi. Itupun kalau ada hal yang negatif tentang kita disampaikannya kepada anak perempuan itu. 'kalau itu suamimu... ini perangainya, bagaimana di hatimu?'... misalkan (saran) kita... 'kalau kami berpendapat jangan lah itu', tapi kalau dia (gadis itu) mau, kalau gitu, ini niatnya kamu jaga, apapun ke depan ada kejadian tidak menjadi penyesalan...." (Yusin Saleh, Kampung Bujang, 02/11/2019)

Akan tetapi, kearifan yang sudah lama digariskan oleh nenek moyang orang Gayo ini tidak serta merta diikuti oleh seluruh orang Gayo Lôt kontemporer, walaupun kemaslahatannya diyakini sangat besar bagi calon keluarga baru yang hendak dibina. Keresahan disuarakan oleh salah seorang informan yang menggambarkan terjadinya pergeseran pemahaman dan tindakan sosial oleh masyarakat Gayo dewasa ini:

“... Sekarang kalau kita bilang masyarakat Gayo ini sekitar 30 persen palingan yang menerapkan itu. Yang namanya amal tidur nipi jêgê itu kan harus berhari-hari dulu.... Ini sekarang... di situ datang nanti memberi amal tidur nipi jêgê, di situ juga terus jawabannya. (Seharusnya) dia mencari lagi latar belakang, background orang itu seperti apa. Kalau memang ada permasalahan, entah itu ga beradab, ga bermoral gitu kan, itu berat (condong) dia menolak...." (Dr. Joni MN, M.Pd, Kampung Pinangan, 09/11/2019) 
Kembali ke tahapan prosesi adat pernikahan di Tanah Gayo. Ketika forum keluarga dari pihak anak gadis itu telah mencapai sebuah kesimpulan, sang ayah lalu mengundang utusan tadi ke rumahnya. Dalam pertemuan itu diberikan jawaban atas tanda yang dititipkan beberapa hari yang lalu oleh pihak keluarga pemuda yang memiliki maksud. Bila jawabannya "ini gêrê neh kami ulakên" (tanda ini tidak lagi kami kembalikan), itu petanda diterima atau terbuka pintu bagi calon mempelai laki-laki (aman mayak). Sebaliknya, bila tanda yang dititipkan itu dikembalikan bermakna ditolak. Dewasa ini, orang Gayo sepertinya mulai beranjak meninggalkan tahapan awal dalam prosesi pernikahan tersebut. Hal ini dilihat sebagai bentuk degradasi nilai adat budaya Gayo dalam prosesi pernikahan oleh informan berikut:

“... Perubahannya udah banyak sekarang ini... Seharusnya kalau itu di awal dia belum meminang. Dia masih istilahnya memberitahu keinginan dan kehendaknya... dikasih simbol... misalnya beras dalam tapë... terus di dalam beras itu nanti ada uang. Sekedar mudahnya. Jadi itu dikasih nanti kepada pihak yang dipinang. Jadi nanti pihak yang dipinang langsung mengatakan, 'ini nanti', katanya, 'kami amal tidur nipi jêgê' dulu. Itu dahulu... Sekarang tidak lagi. Di situ dia memberitahu keinginannya di saat itu juga dia mungintë (meminang). Nah ini yang sudah mengalami degradasi...." (Dr. Joni MN, M.Pd, Kampung Pinangan, 09/11/2019)

Realitas ini melahirkan sindiran dengan sebutan pêrjak tomang. Secara istilah bahasa, pêrjak artinya membajak dan nomang artinya menanam. Bila dua kata disatukan, pêrjak tomang, bermakna membajak dan menanam di waktu yang sama atau tergesa-gesa dalam melaksanakan setiap tahapan prosesi pernikahan. Hal ini sebagai cerminan fenomena masyarakat modern yang ingin serba cepat dan instan sehingga melupakan esensi dan sakralitas nilai-nilai adat.

Mari kita kembali lagi ke prosesi adat yang asli tadi. Setelah terbuka pintu melalui sinyal yang disampaikan oleh pihak keluarga bêru, tahapan selanjutnya mulai masuk ke dalam prosesi meminang atau dalam bahasa Gayo disebut mungintë (Aman Pinan, 2001; Pandapotan, 2017). Hal penting yang perlu diketahui adalah interaksi dalam proses lamaran ini belum melibatkan keluarga inti dari pihak yang hendak meminang, sebagaimana penjelasan tokoh adat Gayo berikut:

“... kalau (jawabannya) 'silahkan datang, kami menunggu’ berarti kira dia pun sudah mau, paling ndak terbuka hatinya mau menerima. Baru datang mungintë (meminang) datang lima atau empat orang, masih dalam hubungan, tapi bukan yang bertanggungjawab, artinya bukan ama (ayah), bukan inê (ibu), mungkin ibi (tante) atau kil (suami tante) atau ngah (adik laki-laki ayah)... bukan yang intinya. Itu baru mungintë (meminang). "tujuan kami ini... ini...." (Yusin Saleh, Kampung Bujang, 02/11/2019)

Jadi delegasi kecil yang berangkat dari pihak calon aman mayak adalah kerabat dekatnya. Kaum kerabat ini berasal dari garis keturunan pihak ibu atau garis keturunan pihak ayah yang 
dinilai tidak terlalu tinggi status otoritasnya di dalam keluarga mereka, tanpa melibatkan aparat Sarak Opat. Namun penampakan prosesi meminang di Tanah Gayo dewasa ini mungkin sedikit bergeser dimana aparat Sarak Opat tidak jarang dilibatkan dan sepertinya sudah menjelma menjadi kesadaran orang Gayo sekarang sebagaimana pengakuan salah seorang Pêtuê Kampung Blang Kolak I berikut:

“... Pada saat meminang, itu... tidak mutlak harus Rêjê dan Pêtuê... Namun yang selama ini kita laksanakan... (masyarakat merasa) seakan-akan itu sudah mutlak di tangan Rêjê dan Pêtuê beserta Imêm...." (Riduwansyah, Kampung Blang Kolak I, 02/11/2019)

Para pengurus Majelis Adat Gayo menilai tindakan pelibatan aparat Sarak Opat ini berbahaya dan bisa berdampak buruk bagi nama baik kampung, sebab dalam proses lamaran belum tentu tercapai kata sepakat. Bila terjadi penolakan, dikhawatirkan membawa aib atau malu bagi kampung pihak calon aman mayak. Sementara menjaga malu adalah budaya tertinggi orang Gayo (Melalatoa, 1985).

Pada saat kegiatan mungintë, andaikata proses lamaran itu diterima oleh pihak keluarga calon inên mayak (calon mempelai perempuan), dalam momen itu sudah diberi gambaran kepada delegasi kecil tersebut berapa jumlah mahar, permintaan (têniron), dan uang hangus. Delegasi kecil ini kemudian pulang dengan membawa gambaran yang diminta sebagai bahan untuk didiskusikan di dalam forum keluarga besar mereka. Setelah itu, pihak keluarga calon aman mayak kembali mengutus delegasi kecil lain. Kali ini anggota yang berangkat adalah keluarga dekat calon aman mayak dari garis keturunan pihak ayah yang memiliki otoritas dalam bernegosiasi. Mereka mengemban tugas membuat kesepakatan dengan pihak keluarga calon inên mayak. Tahapan ini disebut bêtêlah. Informan menggambarkan:

“... sudah setuju, mudah-mudahan jadi jodoh, itu dari gambaran berapa maharnya, berapa têniron (permintaan) yang diminta, kalaupun uang apakah tempat tidur, itu gambarnya sudah ada... misalnya uangnya 20 juta bagaimana? Itu (utusan) pakat lagi di sana (di rumah keluarga calon laki-laki), 'sudah, 12 juta lah nanti kita minta'... itu namanya sudah (mulai) bêtêlah... apa yang diminta supaya dapat dipenuhi, yang terlalu lebih diminta turun... Pulang lagi ke sana (rumah keluarga calon mempelai perempuan)... berarti kalau datang yang ini sudah datang yang inti yang bisa bertanggungjawab. Mungkin pakcik (dari keluarga pihak ayah), itu bertanggungjawab... dia bisa mengambil keputusan... Kalau tadi yang pertama itu karena paman (dari keluarga pihak ibu) itu ndak berani bertanggungjawab... Jadi gambarannya kan sudah ada karena sudah dia beritakan pertama tadi. Kami (pihak perempuan) minta begini... rencana, ya kan. Di pihak sana pun (pihak laki-laki) rencana begini... begini... Di sini tetap di sana minta turun. Nanti dijumpakan..." (Yusin Saleh, Kampung Bujang, 02/11/2019) 
Akan tetapi orang Gayo kontemporer tidak jarang kedapatan menyatukan kegiatan meminang (mungintë) dengan kegiatan negosiasi mahar (bêtêlah). Hal itu sebagaimana keterangan yang disampaikan oleh Imêm Kampung Lot Kala dan Pêtuê Kampung Blang Kolak I berikut ini:

“... ga seperti zaman dulu, kalau sekarang ini kadang-kadang sekalian aja terus sama istilahnya kesepakatan mahar. Kalau dulu mungintë melamar dulu. Setelah diterima berarti sudah siap dilamar. Setelah itu baru mungkin berselang seminggu atau lima belas hari baru nanti ditetapkan mahar..." (Tgk. Ikmal, Kampung Lot Kala, 09/11/2019)

“... Apa saja yang dibahas di dalam mungintë itu? Dan termasuk permintaan dan kesepakatan sebelumnya barangkali. Ini sering kita laksanakan di sini. Antara kedua belah pihak, calon mempelai laki-laki dan calon mempelai perempuan sudah ada kata sepakat. Itu di belakang, istilahnya dia antara dia. Namun di samping itu, oleh pihak perempuan ini pun sudah diceritakannya kepada pihak keluarga. Maka dipersilahkannya lah kita, diizinkan kita datang mungintë. Pada saat mungintë kita sampaikan... sudah ada kata sepakat, sudah diterima pênginten (lamaran) bahasa Gayonya. Lalu kita masuk ke tahapan berikutnya. Itu sering kita bawa sekaligus. Baru munêlah... sudah oke semua... masuk kita tahapan berikutnya menyangkut dengan waktu... hari H... menentukan akad nikahnya......." (Riduwansyah, Kampung Blang Kolak I, 02/11/2019)

Fenomena ini memunculkan keresahan para tokoh adat Gayo. Menurut para tetua adat, era ini ditandai dengan maraknya pemuda dan pemudi berpacaran sehingga mereka seringkali mengambil keputusan berdua atau mendahului keluarga mereka dalam menetapkan jumlah mahar.

“... karena mereka ini sudah selesai... kesepakatan laki dan perempuan... yang mau menikah itu yang sudah bersepakat. Sudah datang sendiri ke rumahnya... kalau dulu... mana boleh. Astaga, bala kita....” (Aspala Bantacut, Kampung Mendale, 09/11/2019)

Pada pernikahan orang Gayo Lôt biasanya terdapat paling tidak tiga hal yang harus dipenuhi, yakni terkait dengan mahar, permintaan yang biasanya berupa barang isi kamar, dan uang hangus (uang kasih sayang) yang terungkap dalam kalimat budaya melengkan: "jênôjông ni ulu, nêmên i kuduk, tênëmëng ni pumu. Kul lë gêrê kitê dokopi, naruë gêrê kitê jêngkali. Ngê si agihagihë si arani jêma”. Bermakna jumlah yang diminta sudah menjadi kesepakatan bersama dan nilainya sesuai dengan kelaziman di daerah itu.

“... Jênôjông ni ulu ini boleh dikatakan... beban yang diberikan oleh pihak perempuan kepada pihak laki-laki... misalnya ada permintaan lemari, tempat tidur, isi kamar... Tênëmëng ni рuти... itulah seperti mahar... Nêmên $i$ kuduk seperti uang kasih sayang. Kalau dulu bahasanya uang hangus...." (Riduwansyah, Kampung Blang Kolak I, 02/11/2019)

Apabila kesepakatan tentang mahar dan permintaan lainnya ini sudah mencapai titik temu, maka prosesi pernikahan ini menuju ke tahapan mengantar emas (mujulê mas). Kesepakatan tentang hari-H akad nikah ditentukan pada momen ini. Meskipun istilahnya mengantar emas, tetapi 
realitasnya yang dibawa hanyalah barang isi permintaan dan sejumlah uang, sedangkan mahar baru diberikan pada saat akad nikah. Mulai tahapan ini, yang perlu dicatat, seluruh kegiatan sudah berada di tangan Rêjê, bukan lagi tanggung jawab penuh keluarga yang punya hajatan.

“... Mengantar emas istilahnya... tapi yang diantar adalah uang saja, kalau emasnya nanti, kalau maharnya kan waktu nikah. Yang diantar nanti adalah apa dia minta selain mahar, mungkin uang 20 juta, dipan satu misalnya kan, kemudian lemari... Nah ini sudah bukan lagi kerja kita karena mengantar emas itu Rêjê. Rêjê yang mengantar Rêjê yang menerima... di rumah calon yang perempuan... karena yang mengawinkan itu Rêjê ... Dia sudah anak Rêjê itu, waktu turunmani (prosesi kelahiran) dulu kan sudah diserahkan pada Rêjê... Setelah itu di situ diputuskan kapan hari H. Biasanya kisaran sebulan. Nah sama-sama mempersiapkan diri....” (Yusin Saleh, Kampung Bujang, 02/11/2019)

Dalam adat Gayo, status anak yang sudah melalui prosesi adat turunmani (sintê môrep yang pertama) menjadikan anak tersebut secara simbolis sebagai anak milik Rêjê dan masyarakat kampung. Ketika anak itu dewasa, konsekuensinya meramaikan acara pernikahannya pun menjadi tanggung jawab bersama. Pada masa lalu, solidaritas kampung berjalan dengan baik karena pemahaman ini masih terpelihara di dalam kesadaran kolektif masyarakat.

“... Jadi sudah mau mujulê mas itu... pihak keluarga sudah memanggil Sarak Opat... diserahkan... Kalau sudah diserahkan seperti itu dulu, itu bujang bêrama bêru bêrinê itu sudah merapat...." (Dr. Joni MN, M.Pd, Kampung Pinangan, 08/12/2019)

Kegiatan mengantar emas sudah melibatkan aparat Sarak Opat. Dalam menyampaikan pesan untuk mengajak keterlibatan aparat Sarak Opat ini, tradisi Gayo Lôt memiliki mekanisme sendiri, dan tata cara ini lagi-lagi terkait dengan simbol atau tanda. Simbol yang dibawa serta oleh keluarga berupa minuman kopi yang bermakna ada pekerjaan dengan tanggung jawab yang besar. Simbol tersebut melambangkan partisipasi yang merupakan tindakan yang harus dijunjung tinggi. “... di dalam adat Gayo ini, bukan uang yang di depan, tapi partisipasinya tinggi.... kemudian banyak uang itu diganti dengan lambang. Lambang itu jadi lebih berat (maknanya)... Contoh, menyampaikan kepada Rêjê bahwa tanggal sekian kita rapat ke rumah, kita mau antar emas misalnya... kan lebih bagus sebenarnya sebagai ucapan terima kasih: amplop, itu malahan menghina. 'Kau diongkos' berarti kan? Tapi ndak... hanya kopi satu cangkir, Bapak datang. Kopi ini yang berat, karena makna kopi itu kami sekarang kerja ini kan pahit... Kerjaan udah saya tinggal, padahal uang ndak dapat... Tanggung jawabnya berat...." (Yusin Saleh, Kampung Bujang, 02/11/2019)

Dalam masa tunggu sebelum hari-H, salah satu mata rantai yang hilang dari rangkaian prosesi pernikahan di Tanah Gayo adalah pelaksanaan igurun. Kearifan lokal igurun sangat bermanfaat sebagai bekal persiapan lahir bathin calon pengantin. Memang pada saat ini sudah diadakan kursus calon pengantin (suscatin) oleh Pemerintah (Kantor Urusan Agama). Keberadaan 
suscatin sepertinya telah menggeser eksistensi igurun. Masalahnya ada hal penting di dalam kegiatan igurun yang tidak dijangkau di dalam kegiatan suscatin sebagaimana penjelasan berikut:

"... calon-calon ini tadi tidak lagi igurun. Seharusnya kalau orang kita dahulu, sebulan sebelum menikah, si calon ini sudah diantar untuk diserahkan ke Imêm, terus ke Pêtuê... Jadi ada dua dia pelajari nanti itu. Satu bidang agama, satu bidang adat. Itu diserahkan ke sana. Itu seharusnya, sekarang tidak lagi, cuman ikut catin aja kan di KUA. Sebenarnya orang kita tidak melarang catin. Itu silahkan karena itu persyaratan, mungkin prosedur dari Peraturan Negara. Tetapi igurun tadi jangan ditinggalkan karena lebih besar dampaknya...." (Dr. Joni MN, M.Pd, Kampung Pinangan, 09/11/2019)

Mengapa igurun ini signifikan dan hal apa saja yang diajarkan dalam kegiatan tersebut? Kearifan lokal ini ternyata berguna sebagai bekal persiapan lahir bathin calon pengantin karena memuat banyak materi pelajaran tentang spiritual, kehidupan, dan interaksi sosial. Hal itu sebagaimana penjelasan berikut:

"... dia belajar dalam 15 hari itu, dia belajar doa, belajar adab, kalau secara agamanya, kan gitu. Nah bagaimana suami istri. Doanya seperti apa, itu yang bisa empat mata, ga mungkin bisa dikasih tahu di depan orang banyak. Nah itu makanya perlu dia diserahkan ke Imam kampung. Nah terus, setelah itu 15 hari kemudian baru dia masuk ke Pêtuê... yang mengajari adat. Supaya dia tahu bagaimana adatnya menghadapi mertua, keluarga seperti apa... sampe sekecil-kecilnya... Sampe bangun tidur itu diatur. Kalau dia masih tinggal sama mertua, cara bangun tidurnya seperti apa. Pagi itu, membuka pintu itu seperti apa... Itu makanya ada kata-kata 'rêmalan ênti bêgêrdak' (berjalan jangan gaduh). Artinya apa... pas pagi-pagi buka pintu... kan dulu rumah orang panggung ya? Jangan sampai tahu yang kanan kiri kita bangun mau mandi itu. Itulah dia maknanya. Sampe sekecil itu. Sekarang itulah yang sudah tidak ada...." (Dr. Joni MN, M.Pd, Kampung Pinangan, 09/11/2019)

Kegiatan kursus calon pengantin yang dilaksanakan oleh Kantor Urusan Agama (KUA) dalam sorotan pemerhati adat Gayo tidak lepas dari permasalahan lain. Pemandangan yang melanggar norma sumang di Tanah Gayo tidak jarang terlihat saat calon pengantin hadir untuk mengikuti kegiatan suscatin ke kantor KUA secara berpasangan dan tidak didampingi oleh keluarga mereka.

"Nah kursus calon pengantin itu dia pergi dari rumah kadang-kadang berduaan. Padahal dia baru kursus, belum akad... berduaan naik sepeda motor udah pegang-pegang pinggang... karena orang tua kadang-kadang malas ngantar anaknya, "udah kamu aja pergi", akhirnya pergi berdua kan....” (Dr. Joni MN, M.Pd, Kantor Majelis Adat Gayo, 16/09/2019)

Bila igurun tampaknya menuju kepunahan, tidak demikian halnya dengan dua kegiatan penting ini. Masyarakat Gayo Lôt sudah terbiasa duduk bersama dalam mempersiapkan suatu acara. Mereka mewujudkan solidaritas tersebut melalui kegiatan pakat sara inê dan pakat sudêrê. Dalam rapat-rapat tersebut dibicarakan kerjasama yang meringankan, pada umumnya berupa 
bantuan benda atau tenaga. Kemudian dibentuk kepanitiaan guna mempersiapkan acara meramaikan pernikahan atau walimahan.

“... kalau pakat sara inê itu pertama, ada yang mau datang, terus kita seperti apa. Orangnya seperti ini... seperti ini... seperti ini... keluarganya gini... terus kita seperti apa? Terus yang kedua kalau dia memang udah mau minang, itu pakat sara inê itu ada nanti yang dibicarakan itu istilahnya kerjasama. Kerjasama meringankan. Nanti dari kamu apa. Oh... dari saya kayu bakar. Dari sini, oh saya sayur. Dari sini nanti, oh saya urusan benten. Nah itu, meringankan bebannya. Satu. Yang kedua membicarakan tata cara kerjanya seperti apa...." (Dr. Joni MN, M.Pd, Kampung Pinangan, 09/11/2019)

“... Kalau pakat sudêrê itu sudah masuk tetangga-tetangga... yang bukan satu induk lah. Itu juga di sana ada yang nyumbang... Ada yang berbentuk benda, ada yang berbentuk uang. Tapi kebanyakan berbentuk benda. Ada yang berbentuk tenaga. Saya jadi tukang cuci piring aja katanya. Ada yang seperti itu. Saya nyambut tamu aja. Istilahnya seperti pembentukan panitia...." (Dr. Joni MN, M.Pd, Kampung Pinangan, 09/11/2019)

Menurut Ketua Majelis Adat Gayo, persiapan acara pernikahan pada masa lalu dikoordinir oleh Rêjê melalui aktivitas yang dinamakan pakat sudêrê. Hal ini berdasarkan pemahaman bahwa kegiatan meramaikan acara pernikahan adalah kegiatan kampung. Informan menegaskan:

“... Nah mungkin misalnya mendekat pada seminggu lagi kerja itu diserahkan kepada $R \hat{e} j \hat{j}$, Rêjê yang mengatur, Rêjê yang membimbingnya, masak siapa, buat ini, buat itu... di (pihak) sana pun nanti demikian, itu persiapan panitia di situ...." (Dr. Joni MN, M.Pd, Kampung Pinangan, 09/11/2019)

Kegiatan lain di dalam prosesi pernikahan secara adat Gayo yang tidak boleh dilupakan yaitu bêrkuru dan bêrguru (Dailami, 2018). Penjelasannya sebagai berikut:

Menjelang hari $\mathrm{H}$, besok mau diantar biasanya mereka jam 4 (sore) begini dia bêrkuru. Bêrkuru artinya intern keluarga, baik dari pihak mamak maupun dari pihak bapak. Itu satu ruangan tertutup. Itu mereka meminta maaf lah segala-galanya di situ antara keluarga dengan dia... Itu tingkat tertinggi... artinya dari hati ke hati, boleh blak-blakan. Memang blak-blakan harusnya, apa yang mengganjal di hati, kalau dia umpamanya jahat, bisa... 'kamu selama ini nakal sekali', bisa... Karena yang dengar cuma intern keluarga. Baru sore nanti atau besok itu diserahkan kepada Rêjê, yaitu bêrguru namanya...." (Yusin Saleh, Kampung Bujang, 02/11/2019)

Informan di atas menjelaskan lebih jauh bahwa bêrguru bisa diibaratkan seperti acara wisuda di perguruan tinggi. Kegiatan ini seolah mengukuhkan bahwa seseorang akan memasuki kehidupan dengan menyandang status baru beserta tanggung jawab yang melekat di dalamnya. Sementara "universitas kehidupan" sudah dilalui sejak ia lahir hingga dewasa yang diperoleh dalam lingkungan keluarga, lembaga pendidikan, dan masyarakat. Berdasarkan hasil triangulasi antara informan penelitian ini, bêrkuru bisa diasosiasikan dengan istilah êjêr marah, sementara bêrguru bisa diasosiasikan dengan istilah êjêr muarah. Selain itu, ternyata ada satu kegiatan lain yang 
berkaitan dengan pengayaan ilmu berumah tangga yang juga disampaikan kepada kedua mempelai melalui kegiatan êjêr mërah yang diperoleh pasca hari pernikahan. Penjelasannya sebagaimana petikan wawancara berikut:

“... êjêr marah... misalnya besok mau menikah, malam ni sama keluarga inti itu... orang tuanya didudukkannya, diambil air... dilayang jeruk purut... dicuci kaki ibunya dulu. Si calon itu yang cuci. Dicuci kaki bapaknya... Pindahkan air. Minta maaf dia dulu ke orang tuanya yang perempuan terus minta maaf ke orang tuanya yang laki-laki. Setelah itu minta izin lagi. Jadi itu harus pisah-pisah, ga sekalian. Setelah itu baru dia mundur, minta diajari... Di sana itu habis-habisan itu diajari. Karena cuman keluarga inti, ga ada masuk orang lain...." (Dr. Joni MN, M.Pd, Kampung Pinangan, 09/11/2019)

“... Ejêr muarah itu tadi, itu ketika mau diantar akad... mungkin jam 10 akad, berarti jam 8-nya. Itulah bêrguru namanya.... Di situ yang ngajarin Imam atau Kepala Kampung kan. Itu sudah tetangga-tetangga pun di situ. Jadi ga ada istilah rahasianya... Cuman muarah aja...." (Dr. Joni MN, M.Pd, Kampung Pinangan, 09/11/2019)

Nah, êjêr mërah itu setelah selesai hari pernikahan itu.... kita kan mengunjungi mana pak kôl (abang ayah yang tertua).... mana ama lah (adik ayah yang tengah), ama ucak (adik ayah yang bungsu)... nanti setelah datang ke sana... dikasih makan kita, terus diajari, pulangnya kita dikasih bawaan, entah tikar, entah piring nanti... Ini yang tidak ada lagi. Manten-manten baru sekarang ini kita bisa lihat dampaknya kalau itu hilang. Akhlak ga ada lagi. Begitu selesai pernikahan, malah pake celana panjang sempit lagi di depan mertuanya. Nah itu karena tidak ada tahapan-tahapan ini tadi..." (Dr. Joni MN, M.Pd, Kampung Pinangan, 09/11/2019)

Kekhawatiran yang disuarakan oleh informan di atas sangat mendasar. Dewasa ini, angka perceraian di Kabupaten Aceh Tengah cukup tinggi, sangat timpang dengan laporan pada masa kolonial Belanda dimana kehidupan rumah tangga orang Gayo digambarkan jarang mengalami perceraian (Hurgronye, 1996). Hilangnya sejumlah rangkaian tahapan prosesi adat pernikahan disinyalir memberi dampak sosial budaya berupa tingginya angka talak dan gugat cerai di Mahkamah Syari'ah Takengon.

Selanjutnya dalam rangkaian prosesi pernikahan di Tanah Gayo, tidak jarang dibudayakan tradisi-tradisi yang mengandung pesan khusus, misalnya tradisi tepung tawar. Sebenarnya tepung tawar ini bisa ditafsirkan sebagai kiasan atau perumpamaan yang mengandung maksud tertentu. Tepung tawar tidak dipandang sebagai suatu aktivitas yang sakral di dalam adat Gayo, tetapi hanya bagian dari budaya adat yang bersifat low superior. Informan berikut mendeskripsikan makna tradisi tepung tawar yang biasa dilakukan orang Gayo:

“... Di dalam tempat cuci tangan itu... ada batang têgôh ... dêdengen, bêbêsi... cêlala. Ada pula kayu kôl. Segala macam. ini kan perumpamaan... 'Wahai anakku, semoga seperti dêdengen ini nanti sejuknya hatimu ... semoga seperti cêlala ini nanti dinginnya maksud keinginanmu. Baik-baiklah kamu, murah hatilah kamu'.... Adakah lihat ditaruh di tangan? 
Ini punya makna... 'Cucuku, atau anakku, atau keponakanku, baik-baiklah tanganmu ini mencari karena tangan inilah yang berusaha. Mulut hanya berbicara, mata hanya melihat, hidung hanya mencium... tapi yang berusaha ini... tangan ini yang menulis, yang menyangkul... semoga tangan ini membawa keberhasilan. Bagus-baguslah bekerja. Cari rezeki yang halal dan baik'... lalu ditaruhnya ke ulu hatinya... 'sejuklah hatimu, jangan ke kanan ke kiri, ikhlaslah dalam segala yang engkau kerjakan'... lalu ditaruhnya ke kepala... 'bagus-baguslah berpikir... yang jelek dibuang, yang tidak baik ditinggalkan. Berpikir yang jernih, serahkan diri kepada Allah', begitulah maksudnya. Siapa tahu ada lagi yang kamu lihat ditaruhnya ke bahu, kan ada itu. "Wahai cucuku, saat ini sudah sampai masamu, sudah ada nanti bebanmu, di kanan ada bebanmu, di kiri ada tanggung jawabmu', itu bagi orang yang menikah itu. Bermakna semuanya. Bukan sembarangan saja..." (Aspala Bantacut, Kampung Mendale, 09/11/2019)

Setelah melalui prosesi adat bêrguru, pada hari-H calon aman mayak diantar bersama-sama ke lokasi pernikahan yang sudah disepakati. Kegiatan mengantar mempelai ini dipimpin langsung oleh Rêjê disertai dengan keluarga dan masyarakat kampung, disebut dengan istilah mujulê bai. Di sisi lain, pihak mempelai perempuan sudah menunggu di kampung mereka, yang dipimpin oleh Rêjê kampung setempat. Kemudian terjadi prosesi yang dilakukan antara pihak laki-laki dan pihak perempuan yang disebut penyerahan dan penerimaan rêmpêlë (mempelai).

“... Serahkan ke pangkuan Rêjê... untuk mengantarkannya... dan kami (keluarga) mengiringi untuk pergi ke tempat nikah... Di sana pun begitu juga kejadiannya sama, nanti mereka menerima, sama-sama di tempat nikah..." (Yusin Saleh, Kampung Bujang 02/11/2019)

“... Jadi kalau pihak perempuan menunggu pihak laki-laki datang. Nanti tempatnya kesepakatan terserah, kalau sekarang ada di KUA, ada di masjid, ada di rumah kan. Tergantung kesepakatan kedua belah pihak... begitu acara akad nikah nanti di dalamnya juga ada... penyerahan pihak laki-laki kepada pihak perempuan namanya penyerahan rêmpêlë (mempelai) beserta di situ penerimaan rêmpêlë. Itu yang secara adatnya harus ada...." (Tgk. Ikmal, Kampung Lot Kala, 09/11/2019)

Pelaksanaan prosesi akad nikah di KUA mendapat kritikan tajam dari para tokoh adat Gayo.

Alasannya prosesi adat sintê mungêrjê tidak lagi dilakukan atau terlalu disimplifikasi bila lokasinya bertempat di ruang KUA yang sempit.

“... kalau sudah mengantar pengantin ke KUA sudah berjumpa lutut diantara kita... semuanya di sana, dimana ada orang mêlëngkan ... tapi yang sedihnya seperti itu, tidak ada diserahkan mereka kepada kita, ada kejadian nanti dikembalikannya kepada $R \hat{e} j \hat{e} . .$. kalau begitu jangan kerjakan lagi... diamkan terus. Itulah makanya kami juluki pêrjak tomang. Bagaimana maksudnya pêrjak tomang? Di situ meminang, di situ kesepakatan mahar, di situ antar emas atau apa, karena itu tadi, sudah bersepakat di awal. Lalu besoknya nikah. Nikahnya pun di KUA... Tak ada lagi bicara antara Rêjê dengan Rêjê... Itu sudah lari dari adat...." (Aspala Bantacut, Kampung Mendale, 09/11/2019) 
“... Kalau dilakukan di KUA itu biasanya seremonial adat seperti menyerahkan mempelai oleh aparat Sarak Opat dan menerima mempelai juga oleh Sarak Opat itu hampir tidak ada dilakukan. Dianggap selesai, hanya Imam berjumpa dengan Imam, dia berjabat tangan, sambil menyerahkan mahar dia nyatakan ini sudah kami antar mempelai laki-laki. Nah, sudah kami terima. Kita kasih hukumnya, kita kasih ijabnya, kan begitu. Lalu proses, setelah proses selesai..." (Anda Putra, S.H, Pasar Pagi Lama, 02/11/2019)

Kembali ke prosesi adat sintê mungêrje. Dalam pernikahan orang Gayo yang beragama Islam, kegiatan yang paling sakral adalah pelaksanaan akad nikah itu sendiri. Akad nikah adalah salah satu syarat sah suatu pernikahan sehingga sifatnya high superior baik dilihat dari sisi agama maupun adat Gayo. Agar kegiatan ini berjalan dengan lancar, mempelai laki-laki biasanya sudah ditatar terlebih dahulu oleh Imêm di kampungnya. Ia sudah latihan dalam mengucapkan ijab qabul yang benar dan sah. Setelah proses akad nikah dilakukan, dilanjutkan dengan khutbah nikah dan makan bersama. Kemudian masing-masing perwakilan aparat Sarak Opat menyampaikan sepatah dua patah kata. Di sisi yang lain masing-masing ibu pengasuh dari kedua mempelai bertukar sirih (mangas) di dalam wadah yang bernama batil. Pertukaran simbolis ini juga biasa dilakukan pada tahap peminangan yang sudah dijalankan sebelumnya.

“... Itu bawaannya... batil. Batil tu tempat sirih oleh ibu pengasuh dari laki-laki, dari pihak perempuannya juga gitu... Tukar mangas (sirih).... Setelah itu, karena sudah habis... (pihak keluarga mempelai laki-laki) minta izin pulang...." (Riduwansyah, Kampung Blang Kolak I, 02/11/2019)

Kepulangan keluarga tidak diikuti oleh mempelai laki-laki. Malam pengantin dilewati di rumah orang tua mempelai perempuan. Selama seharian itu, kegiatan yang dilakukan sudah berada di luar prosesi adat, yaitu berupa acara keluarga yang dibudayakan dengan menjamu tamu undangan dan mengadakan hiburan.

“... Cuma nanti bergantung kepada acara keluarga... mungkin ada entah band... itu terserah, sudah masing-masing... Bukan adatnya lagi. Budaya adat. Ada yang meramaikan, ada yang... terserah... macam-macam. Dalam arti kata, tidak bertentangan dengan agama.... Menggambarkan itu ndak dilarang oleh orang banyak, senang orang melihatnya. Adabnya bagus, adabnya baik, nah itu... silahkan masuk..." (Yusin Saleh, Kampung Bujang, 02/11/2019)

Kegiatan walimahan biasa disebut oleh orang Gayo kontemporer sebagai pesta. Namun studi Bakti, et al. (2020) menemukan fakta lain. Pesta adalah sebuah pilihan kata yang sudah terdistorsi dari akar kata aslinya, "sintê". Kata pesta yang memiliki muatan ideologi konsumerisme global pada kenyataannya telah mereifikasi makna sintê. Reifikasi memudahkan proses konsumerisasi pesta sehingga kerapkali menampilkan hal-hal baru yang tidak terbayangkan sebelumnya, membunuh solidaritas masyarakat karena terjadi pergeseran dari ekspresi 
kebersamaan (Selian, 2007) menjadi kontestasi nilai-tanda (Baudrillard, 1970), menegaskan perbedaan status (Veblen, 1899; Bakti, et al., 2020), dan beragam rentetan masalah yang membuntutinya.

Pada masa kini, hiburan dalam acara resepsi pernikahan diisi dengan bernyanyi yang diiringi oleh kibot. Bentuk hiburan yang ditampilkan sudah mengalami banyak perubahan. Menurut informan, kegiatan hiburan dalam acara pernikahan masuk ke dalam kategori low superior atau budaya adat. Hal itu sebagaimana keterangan berikut ini:

“... Ya. Itu masuk ke low. Bukan superior pun... Karena di tempat kita itu ga dianjurkan harus ya... harus istilahnya... panggil band... Canang aja cukup... jadi dulu canang... Itu aja udah rame. Sebenarnya itu pun tidak masuk ke dalam sakral. Itu masuk ke dalam ritual untuk menghibur orang yang kerja. Itulah dia. Tujuannya ke sana. Nah, orang yang cuci piring, orang yang ikut membantu... masak... hiburannya nanti itu..." (Dr. Joni MN, M.Pd, Kampung Pinangan, 09/11/2019)

Selain canang, pada masa lalu keramaian acara pernikahan di Tanah Gayo diisi dengan hiburan berupa kesenian tradisional yang masuk dalam kategori budaya adat (low superior). Pada era 1980-an, hiburan ini kemudian mulai tergeser dengan diperkenalkannya band, orkes, dan kibot. Sejumlah informan mengingat kembali proses diintrodusirnya budaya kibot di Tanah Gayo dalam beberapa petikan wawancara berikut:

"Itu (kibot) ndak ada dulu... itu (yang ada) tari guel misalnya kan, tari munalo misalnya...." (Riduwansyah, Kampung Blang Kolak I, 02/11/2019)

"Ada mungkin dari beberapa orang karena faktor... kombinasi pemikiran yang kekinian mungkin... Ada saudara yang sudah merantau, pas acara pesta mungkin balik ke mari, ada saran, atau sebagian mungkin dasarnya kibot itu adalah bahagian dari keluarganya... 'karena om itu orang kibot ya udah, om itu aja kibot di sini buat hiburan kita'. Nah, terus perlahanlahan karena orang yang datang di hajatan itu kan orang rame, melihat... ada ketertarikan... Perubahan kan seperti itu. Dari tidak ada, melihat sesuatu yang baru, kemudian ada ketertarikan, terus dan terus...." (Anda Putra, S.H, Pasar Pagi Lama, 02/11/2019)

"Yah itu (kibot) barangkali ya... baru 30 tahun ini adanya itu. Kalau dulu ndak ada... ndak ada pun nyanyi-nyanyi, biasa saja dia... mungkin nanti malam bersyair. Jadi diundang itu orang datang... kita pun dengar di sini. Jadi yang disyairkan itu naskah agama, berdasarkan uraian ayat atau naskah berdasarkan uraian hadis atau cerita yang mengandung makna... atau ndak syair mungkin, group didong... bedidong sini.... nah sekarang ini tergeser kan...." (Petikan wawancara dengan Bapak Yusin Saleh, Pengurus Majelis Adat Gayo)

“... Baru saya rasa. Itu paling-paling baru 25 tahun yang lalu ada kibot... kalau ga mana pernah ada kibot, orkes kalau bahasa orang zaman. Mana ada ditonton orang orkes. Mic aja barusan ada, mana ada pernah berkibot... begitulah...." (Aspala Bantacut, Kampung Mendale, 09/11/2019) 
“... Sekitar tahun 80-an baru ada kibot. 85 mungkin. Ya...85. Kalau di sini ya? Sekitar 80an ke atas. Kalau 70-an belum ada.” (Riduwansyah, Kampung Blang Kolak I, 02/11/2019)

Dalam penafsiran informan, agama sebenarnya memperbolehkan hiburan dalam acara walimahan. Hal itu dapat disimak pada keterangan berikut:

“... Kalau kita melihat dari sudut pandang agama, sebenarnya tidak ada larangan, bahkan, ini tolong digarisbawahi... itu dianjurkan, karena ada sebuah hadis mengatakan, kira-kira maknanya begini, lakukan akadnya itu di masjid, setelah itu adakan walimah, potonglah kibas, dan adakan pertunjukan rebana. Itu hadis dan... sampai hari ini hasil penelitiannya bukan hadis kaleng-kalengan lah... Jadi pertunjukan rebana itu kalau kita maknai bisa artinya itu kan hiburan. Nah persoalannya sebenarnya dimana? Isi dari hiburan itu, ini yang sebenarnya jadi persoalan...." (Anda Putra, S.H, Pasar Pagi Lama, 02/11/2019)

Pernyataan terakhir di atas sesungguhnya mewakili kritik yang dilontarkan oleh para sesepuh adat dan pemuka agama yang selama ini melihat ada kejanggalan pada pelaksanaan hiburan dalam acara walimahan. Mereka merasa hiburan kibot mudah menjerumuskan masyarakat ke dalam jurang kemaksiatan. Jadi, bila dikaitkan dengan konsep sebelumnya, hiburan kibot ini bahkan dipandang sudah berada di luar dari ritual/budaya adat (bukan lagi budaya adat), karena aktivitasnya seringkali berbenturan dengan nilai dan norma adat, bahkan nilai dan norma agama itu sendiri.

“... Kita membawakan lagu-lagu yang kadang-kadang tidak etis. Itu. Kemudian yang membawakannya mungkin pakaiannya terlalu mengumbar bentuk auratnya... bagaimana kita berusaha tidak masuk ke dalam hiburan itu nuansa-nuansa yang bertentangan dengan syariat dan agama. Itu letak persoalannya...." (Anda Putra, S.H, Pasar Pagi Lama, 02/11/2019)

Kurang dari 3 dasawarsa yang lalu, Bowen (1993) melakukan sebuah studi dan mengklasifikasi orang Gayo Lôt ke dalam dua orientasi keagamaan yang dijuluki sebagai kom tuê dan kom mudê. Berdasarkan pengamatan di lapangan, jama'ah Muhammadiyah di Kabupaten Aceh Tengah yang dikategorikan sebagai kom mudê kebanyakan tidak menampilkan hiburan berupa kibot dalam menyelenggarakan walimahan. Hal ini dapat berjalan karena adanya struktur kelompok, berupa nilai dan norma, yang mengikat jama'ah tersebut. Tanpa hal ini, rasanya sulit melawan tradisi yang sifatnya kekinian. Menurut informan yang merupakan anak dari tokoh Muhammadiyah tulen:

“... kalau secara dalil tidak ada dilarang itu. Lalu kenapa ada ulama yang melarang? Sebagian tengku-tengku kita... sesepuh kita melarang. Sebenarnya mereka melarang itu, mereka merasa yakin, sulit umat ini menghilangkan kemaksiatan dalam hiburan itu. "Aaah, ga mungkin, kalau sudah hiburan pasti nanti ujung-ujungnya yang ga ga itu”. Terakhir mereka veto terus dari awal. Udah, haram itu. Sebenarnya... kecenderungan mereka ingin memelihara umat supaya tidak terjerumus kepada maksiat. Tapi kalau secara dalil naqli, 
Al-Qur'an dan Hadis, tidak ada larangan itu, bahkan di Hadis dianjurkan, khusus waktu walimah pernikahan. Jadi persoalannya di unsur maksiatnya, bukan di hiburannya...." (Anda Putra, S.H, Pasar Pagi Lama, 02/11/2019)

Orang Gayo Lôt sudah umum melaksanakan dua kali acara resepsi pernikahan, satu acara diselenggarakan di tempat mempelai perempuan dan satu acara lagi diselenggarakan di tempat mempelai laki-laki. Tenggat waktu pelaksanaan kedua acara resepsi tidak terlampau jauh, umumnya berselang satu hari.

“... itu dilaksanakan di daerah Gayo ni... tenggang waktunya... satu hari setelah itu. Misalnya hari ini nikah, ijab qabul, besoknya baru ke tempat pihak kita laki-laki. Balasannya. "Têbang bêrbêlês cêding bêrtunês" kata bahasa sini. "Jurah bêrjamut sêrah bêtêrimê"... cuman... ijab qabulnya ndak lagi kan... tertib acaranya... sama...." (Riduwansyah, Kampung Blang Kolak I, 02/11/2019)

Pada acara resepsi yang kedua, Rêjê beserta keluarga dan masyarakat kampung mempelai perempuan mengantar kedua mempelai ke kediaman orang tua mempelai laki-laki dengan bawaan berupa alun dan têmpah. Kedatangan mereka biasanya disambut dengan tari guêl. Bagi keluarga mampu, terkadang pada malam harinya diadakan pertunjukan kesenian didong.

“... Nanti di situ tidak ada acara yang sakral sekali seperti akad nikah ini... Acara hanya penyerahan kembali pihak mempelai laki-laki ke pihak keluarganya, sekalian penyerahan mempelai perempuannya....” (Tgk. Ikmal, Kampung Lot Kala, 09/11/2019)

“... kalau ndak (dibalas) ya ndak apa-apa, udah sah nikahnya itu. Tapi barangkali ya di tempat saya pun ada (mempelai laki-laki), tinggal Rêjê sana mengantarkan... balik kemari, sambil menyerahkan bawaan. Itu bawaannya mungkin ada pertama alun. Alun itu berarti tanda mata lah, bungong jaroe (Aceh), kepada orang-orang tertentu di dalam keluarga. Harga tidak mahal... Kemudian ada têmpah. Têmpah itu bawaan dia sendiri... untuk kebutuhan dia sendiri... Nah itu juga... mungkin bedidong kadang malamnya atau... terserah lah.... Meramaikan..." (Yusin Saleh, Kampung Bujang, 02/11/2019)

Setelah acara resepsi berakhir, kegiatan semacam pembubaran panitia juga biasanya dilaksanakan oleh keluarga yang punya hajatan. Dalam kegiatan ini pihak keluarga mengucapkan terima kasih dan penghargaan kepada aparat Sarak Opat dan masyarakat kampung yang telah membantu terselenggaranya hajatan pernikahan anak mereka. Dalam acara ini umum disajikan hidangan ringan seperti kopi/teh dan kue saja.

“... berarti udah selesai (dengan masyarakat)... karena tadi diserah, maka sekarang ini minta izin... satu hari atau dua hari kemudian, diundangnya masyarakat kampung ini ke tempat dia dengan kemudahan saja. Tidak ada lagi harus makan, mungkin kue saja. Atau kalau dia mau mungkin makan kita di sini. Dia minta izin ucapan terima kasih kepada Rêjê, Rêjê pun mengucapkan terima kasih kepada anda dan mungkin ada kurang-kurangnya mohon maaf, baiknya demikian ya. Itu udah selesai...." (Yusin Saleh, Kampung Bujang, $02 / 11 / 2019)$ 
Prosesi pernikahan secara adat disempurnakan dengan satu kegiatan terakhir yang dilaksanakan pasca resepsi. Diantara keluarga mempelai perempuan dan keluarga mempelai lakilaki mengisinya dengan acara mah kêrô opat ingi atau mangan bêrumë. Acara makan bersama dua keluarga besar yang sudah menjadi besan ini dilaksanakan di kediaman orang tua mempelai perempuan, dilanjutkan dengan acara saling berkenalan. Para anggota keluarga yang hadir dari kedua belah pihak diperkenalkan satu per satu, sebagaimana penjelasan berikut ini:

“... Mah kêrô opat ingi ini, itulah kalau kita terjemahkan dalam bahasa Indonesia: makan bersama... umë bêrumë... Di situ baru diperkenalkan intinya... saudara pihak laki-laki, pihak perempuan... saling berkenalan lah. Si kôneng tênarôhe (yang kuning telurnya)... Ini wawaknya. Ini pakciknya. Ini pakcik bungsunya. Kemudian ini tante dan suaminya... Ini kakek dari pihak ibu dan ini kakek dari pihak ayah. Gitulah bahasanya...." (Riduwansyah, Kampung Blang Kolak I, 02/11/2019)

“... Tinggal antara mereka dengan mereka... entah hari keempat (atau bisa hari yang lain), dari pihak pengantin laki-laki ini, keluarga... itu pertama sekali istilahnya mah kêrô... bukan bawa nasi sebenarnya, ikan dia bawa. Nah masaknya di sana, di tempat perempuan. Dimasakkan bersama-sama untuk pertemuan mereka sama mereka, biasanya makan siang... itulah dia baru kenalan... ini paman ini... kerja di Banda Aceh... ini polin... saling berkenalan, apa panggilan untuk dia, siapa dia, itu diperkenalkan baik dari perempuan maupun dari pihak laki. Nah itu berarti selesai. Itulah barangkali prosesi pernikahannya sampai di situ...." (Yusin Saleh, Kampung Bujang, 02/11/2019)

\section{Ruang Sakral dan Ruang Ritual dalam Prosesi Pernikahan}

Secara konsep, sakralitas berhubungan dengan suatu hal yang superior atau dihormati. Sebaliknya profanitas berhubungan dengan hal-hal yang biasa saja (Durkheim, 1912). Sakral (kudus) adalah suatu hal yang jauh dari pencemaran, dimuliakan, dan tidak ternoda (Muhammad, 2013). Tantangan besar yang dihadapi adalah fenomena menghambarnya rasa tentang yang sakral. Hal ini terjadi akibat desakralisasi yang terus-menerus menerpa kebudayaan Gayo. Menurut Wulandari (2014), fenomena desakralisasi terjadi karena dua hal. Pertama, kurangnya pemahaman karena hanya menonjolkan aspek ritualitas yang berulang. Kegiatan yang dilakukan tinggal seremonial atau upacara belaka, sehingga ritus menjadi tidak lagi bermakna sama sekali (Bunyamin, 2012). Kedua, transformasi politik dan sosial budaya yang dipengaruhi modernisasi.

Menurut informan, agama dan adat terkait dengan sesuatu yang sifatnya sakral, sementara budaya adat erat kaitannya dengan sesuatu yang sifatnya ritual, seperti penjelasan berikut:

“... Kalau yang sakral itu yang jelas dia itu berhubungan dengan agama itu. Kalau itu kita tinggalkan bisa-bisa pernikahan itu tidak sah. Nah itu salah satunya. Jadi istilahnya ada yang high superior... dia absolutely absolute. Artinya kalau kita tidak kerjakan itu jangankan di agama, di adat pun ga sah... Terus ada lagi yang superior... itu kalau kita 
tinggalkan secara agama sah, secara adatnya mungkin agak rancu. Terus ada lagi yang low superior... itu kalau ditinggalkan secara adat pun ga apa secara agama pun ga apa. Itu memang ritual..." (Dr. Joni MN, M.Pd, Kantor Majelis Adat Gayo, 16/09/2019)

Informan menambahkan bahwa ritual adat mesti berjalan beriringan dengan agama Islam. Ketika ada suatu ritual yang bertentangan dengan agama, maka hal itu hendaknya ditinggalkan, sebagaimana kutipan pernyataan berikut:

“... kalau kita orang Gayo kan lebih ke adat ya. Di adat itu kan ada dua ini... yang pertama itu nilainya adalah sakral, yang kedua tadi ritual. Jadi kalau sakral ini wajib secara adat, harus diikuti, tidak boleh tidak. Kalau ritual ini bisa saja ditinggalkan ketika itu bertentangan dengan agama. Kalau yang sakral ini... sudah ada filterisasi... itu tidak ada lagi bertentangan dengan agama.... Nah kalau yang ritual, kalau itu yang bermanfaat bagi orang lain dan tidak meninggalkan konsep agama, silahkan. Tapi kalau itu mengganggu konsep sakral atau keagamaan itu dan juga mengganggu orang lain itu ditinggalkan...." (Dr. Joni MN, M.Pd, Kantor Majelis Adat Gayo, 16/09/2019)

\section{PENUTUP}

Prosesi adat pernikahan (sintê mungêrjê) adalah utang hidup terakhir yang wajib ditunaikan oleh orang tua dalam daur hidup orang Gayo yang disebut sintê môrep. Penyelenggaraan prosesi sintê mungêrjê selalu melibatkan peranserta keluarga besar (extended family) dimulai sejak proses mencari jodoh hingga kegiatan mangan berumë pasca resepsi pernikahan. Masyarakat kampung (sudêrê) juga terlibat aktif dalam menyukseskan kenduri sintê mungêrjê karena hajatan tersebut dipahami sebagai acara milik Rêjê, ditandai sejak tahapan meminang (mungintë). Dengan demikian, jelas bahwa hakikat sintê adalah spiritualitas dan komunalitas yang diwarnai oleh tahapan kegiatan yang bersifat sakral (high superior dan superior) dan ritual (low superior). Setiap tahapan memiliki makna subjektif sebagai buah dari eksternalisasi generasi pendahulu sehingga diwariskan menjadi kearifan lokal Gayo dalam tradisi pernikahan. Namun seperangkat norma ini tidak lagi terinstitusionalisasi di tengah masyarakat Gayo modern sehingga melahirkan ritual miskin makna dan budaya tanpa identitas kepribadian yang jelas.

\section{DAFTAR PUSTAKA}

Aman Pinan, A. R. H. (2001). Daur Hidup Gayo. Pemerintah Daerah Kabupaten Aceh Tengah.

Bakti, I. S. (2020). Reification of the Signified and Consumerization of Wedding Reception Sintê Mungêrjê in the Gayo Lot Society in Central Aceh District. Sodality: Jurnal Sosiologi Pedesaan, 8(2), 15-35.

Bakti, I. S., Anismar, \& Amin, K. (2020). Pamer Kemewahan: Kajian Teori Konsumsi Thorstein Veblen. Jurnal Sosiologi USK, 14(1), 81-98.

187 | Jurnal Ilmu Sosial dan Ilmu Politik Malikussaleh (JSPM) Volume 1 Nomor 2 Tahun 2020 
Baudrillard, J. (1998 [1970]). The Consumer Society: Myths and Structures. SAGE Publications.

Bowen, J. R. (1984). The History and Structure of Gayo Society: Variation and Change in the Highlands of Aceh. A Bell \& Howell Company.

Bowen, J. R. (1993). Muslims through Discourse: Religion and Ritual in Gayo Society. Princeton University Press.

Bunyamin, A. S. (2012). Sakral dan Profan dalam Kaitan dengan Ritus dan Tubuh: Suatu Telaah Filsafati melalui Agama dan Konsep Diri. Melintas, 28(1), 23-38.

Dailami, I. (2018). Majelis Adat Gayo dalam Melestarikan Adat Beguru di Aceh Tengah sebagai Nilai-Nilai Dakwah. Skripsi. Fakultas Dakwah dan Komunikasi Universitas Islam Negeri Ar-Raniry Banda Aceh.

Durkheim, E. (1912). The Elementary Forms of the Religious Life. George Allen \& Unwin Ltd.

Hurgronye, C. S. (1996). Gayo: Masyarakat dan Kebudayaannya Awal Abad ke-20. Balai Pustaka.

Ibrahim, M. \& Aman Pinan, A. R. H. (2009). Syariat dan Adat Istiadat. Yayasan Maqamammahmuda.

Islami, I. P. (2018). Nilai-Nilai Islam dalam Upacara Adat Perkawinan Etnik Gayo (Kabupaten Aceh Tengah). Skripsi. Program Studi Sejarah dan Peradaban Islam Fakultas Adab dan Humaniora Universitas Islam Negeri Syarif Hidayatullah Jakarta.

Marcuse, H. (1991). One-Dimensional Man: Studies in Ideology of Advanced Industrial Society. Routledge.

Marvasti, A. (2004). Qualitative Research in Sociology: An Introduction. SAGE Publications.

Melalatoa, M. J. (1985). Kebudayaan Gayo. Balai Pustaka.

Muhammad, N. (2013). Memahami Konsep Sakral dan Profan dalam Agama-Agama. Jurnal Substantia, 15(2), 268-280.

Pandapotan, S. (2017). Proses Peminangan Menurut Adat Istiadat Gayo di Desa Kala Lengkio Kecamatan Kebayakan Kabupaten Aceh Tengah. Jurnal Pendidikan Ilmu-Ilmu Sosial, 9(1), 72-83.

Selian, R. S. (2007). Analisis Semiotik: Upacara Perkawinan "Ngerje” Kajian Estetika Tradisional Suku Gayo di Dataran Tinggi Gayo Kabupaten Aceh Tengah. Tesis. Program Studi Pendidikan Seni Program Pascasarjana Universitas Negeri Semarang.

Siregar, M. (2019). Marriage Ceremony in Batak Toba Tribe: Between Consumerism and Purpose of Life. International Journal of Applied Science, 2(3), 40-50.

Veblen, T. (2007 [1899]). The Theory of the Leisure Class. Oxford University Press.

Wulandari, T. (2014). Agama Antara yang Sakral, yang Profan, dan Fenomena Desakralisasi. Refleksi, 14(2), 165-177. 